\title{
Elderly People's Perspective on Rural Medical Care - a Case Study from Northern Germany
}

\author{
Eva Maria Noack, Holger Bergmann
}

\begin{abstract}
Germany's population is decreasing and experiencing accelerated ageing. In 2060, more than a third of the population will be aged 65 years or older. With demographic change, many rural regions are struggling to ensure supply of appropriate public infrastructure while becoming less densely populated and experiencing an increasing share of immobile population groups. One of the major issues at stake is to maintain medical infrastructure at the necessary level. Although health care in Germany is still of very high standard in international comparison, in some rural areas its provision tends to be problematic. Demographic developments aggravate this situation because of two reasons: firstly, natural decline in population and rural depopulation will lead to changes in the rural spatial structure and have impact on the provision of health care; secondly, the growing proportion of older people will simultaneously increase the demand for medical care because, with advancing age, people seek medical treatment more often than at a young age. Even so, older people's specific needs have long been and still are neglected in health care issues. This paper presents findings of an empirical study on older people's mobility options, obstacles that constrain the access to health care and related needs.
\end{abstract}

Key words: demographic changes, older people, medical service, medical care, rural areas, Germany

\section{Stavovi ljudi starije životne dobi o zdravstvenoj skrbi u ruralnim područjima - studija slučaja iz sjeverne Njemačke}

Stanovništvo Njemačke se smanjuje i ubrzano stari. Godine 2060. više od trećine stanovnika bit će starije od 65 godina. Uz demografske promjene, mnoga ruralna područja sve teže osiguravaju adekvatnu javnu infrastrukturu, dok u isto vrijeme ta područja postaju sve rjeđe naseljene uz povećan udio prostorno slabo pokretljivih populacijskih grupa. Jedan je od glavnih problema kako održati medicinsku infrastrukturu na prikladnoj razini. Održavanje visokog standarda zdravstvene skrbi u Njemačkoj u ruralnim područjima zna biti problematično. Demografski trendovi otežavaju ovu situaciju iz dva razloga: kao prvo, prirodni pad stanovništva i ruralna depopulacija dovest će do promjena u ruralnoj prostornoj strukturi i utjecat će na pružanje zdravstvene skrbi; kao drugo, rastući udio starog stanovništva istovremeno će povećati potražnju za zdravstvenom skrbi jer stariji ljudi češće traže medicinsku pomoć. Unatoč tome, specifične potrebe ljudi starije životne dobi dugo su bile i još uvijek jesu zanemarivane po pitanju zdravstvene skrbi. Ovaj rad predstavlja saznanja dobivena iz empirijskog istraživanja o mogućnostima mobilnosti ljudi starije životne dobi, preprekama koje im ograničavaju pristup zdravstvenoj skrbi i potrebama koje se na to odnose.

Ključne riječi: demografske promjene, starije osobe, zdravstvena zaštita, medicinska njega, ruralna područja, Njemačka

Please cite this article as: Noack, E. M., Bergmann, H., 2011: Elderly 


\section{DEMOGRAPHIC CHANGE, A CHALLENGE FOR THE PROVISION OF HEALTH CARE}

Demographic developments, especially low birth rates, rising life expectancy and the ageing of the baby boomer generation, have led to an increasing proportion of elderly people in Germany's population. Already today, Germany is one of the countries worldwide with the largest share of older people and the trend will be upward in the near future: today, $20 \%$ of the population is aged 65 or older. In 2060, this will apply to more than a third of the population and every seventh person will be 80 years of age or older (Fig. 1) (StBA, 2009; BiB, 2009; RKI, 2006).

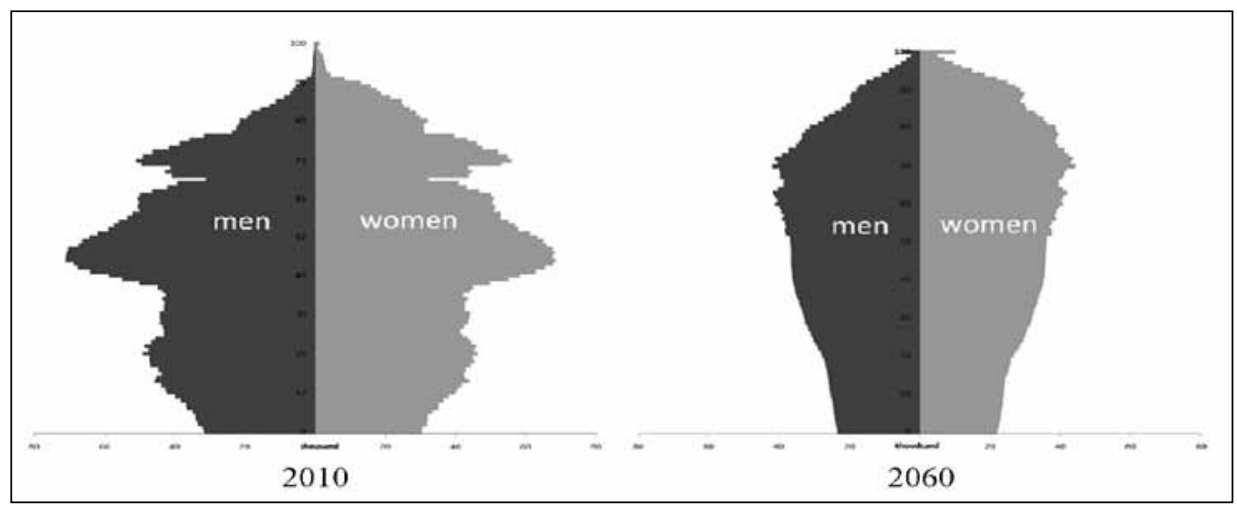

Fig. 1 Age pyramids for Lower Saxony (study area) for 2010 (left) and 2060 (right).

Data for 2060 according to the 12th coordinated Populations projection, medium model. Assumptions: nearly constant birth rate at 1.4 children per woman; annual net migration $+100,000$ persons starting from 2014.

(Own design, according to data from: LSKN, 2011c)

Sl. 1. Dobne piramide za Donju Sasku (proučavano područje) za 2010. (lijevo) i 2060. (desno). Podaci za 2060. prema 12. koordiniranoj Populations projekciji, srednji model. Pretpostavke: gotovo stalna stopa nataliteta od 1.4 djeteta po ženi; neto godišnja migracija +100000 osoba počevši od 2014. (Autori, prema podacima iz: $L S K N$, 2011c).

At the same time, the total population size will decrease: fertility rates in Germany have been low for years now ${ }^{1}$ leading to accelerated irreversible ageing and creeping demographic shrinkage.

In many rural, structurally less favoured regions, this trend is intensified by out-migration of the younger generation. Rural depopulation and ageing entail massive changes in the rural spatial structure. The impact of these fundamental demographic changes differs very substantially from region to region. In general, economically weaker regions face the prospect of further shrinkage while stronger regions are likely to have a stable population or even experience population growth. Economically and demographically, there are marked east-west and north-south divides in Germany: despite the massive subsidies that have been poured into the 'new' Eastern federal states (Länder), Germany continues to bear the marks of the old border that demarcated the political systems. Out-migration still plays an important role; some parts of Germany's needy east are simply drained 
empty. In the future, Eastern Germany will continue to be one of the main population losers. In the more prosperous west, in turn, the southern federal states tend to be better off in relation to the northern part. In the north-west, there are some pockets of economic and demographic disadvantage, like the district of Holzminden (see below) (Cassens et al., 2009; BBR, 2005; 2004).

For decades, German regional development policy has been based on the goal of 'equivalence' of living conditions. ${ }^{2}$ Today, the adjustment of urban and rural living conditions is mainly fulfilled. Yet, ageing and shrinking of the population result in a dismantling of infrastructures in sparsely populated regions. The maintenance of services and facilities (for example, public transport, community centres, post offices) becomes financially unviable, this giving rise to a new disadvantage of rural residences. Above all, the greatest issue at stake is to maintain educational and medical infrastructure at the necessary level (Kopetsch, 2005; Schweikart, 2008). The latter presents a particular problem seeing the growing demand for medical care in an ageing population: with advancing age, people seek medical treatment significantly more often than at a young age. On average, people go to see a general physician 4.2 times a year (standard deviation 6.3), those over 65 years 6.4 times (standard deviation 7.9) (Noll and Weick, 2008; GBE, 2010; see also Böhm et al., 2009; StBA, 2004).

Moreover, the right to live is one of the most important inalienable rights and it implicitly includes the right to a healthy life. Health ranks first when people are asked about the requirements for a happy life. That is why the main policy objective and field of action is to design the health care system in a way that every citizen has access to adequate medical care. This is where requirement planning comes into play: it calls for a supply structure that guarantees comprehensive out-patient, hospital and nursing care in compliance with regional conditions. Primary medical care, for example, has to be reachable in a reasonable period of time (BBSR, 2009). The current system of requirement planning ${ }^{3}$ in Germany controls primarily the regional distributions of physicians approved by the public health scheme $^{4}$ (the so-called 'Kassenärzte'), but respective calculations do not take into account the actual demand or morbidity of the population in a planning region (Kopetsch, 2005; Schweikart, 2008).

Although the health care provided under the German system is still of high standard in international comparison, Germany has to meet the challenge to adapt the (primary) medical care system to demographic and structural changes. ${ }^{5}$ In spite of growing political awareness of the problematic nature of the provision of health care in rural areas with ongoing demographic ageing and enduring economic problems, very few studies deal with these topics in Germany and little work has been done regarding the elderly people in rural areas.

Identifying ways to meet the health care needs of elderly people is crucial, not only because their number and share in the population are increasing, but also because they tend to have more age-specific health care issues (Fendrich and Hoffmann, 2007; Van den Akker et al., 2001). Moreover, they are more likely to experience limited mobility and this could well restrict their access to health care facilities (see for example Mollenkopf et al., 2005; Noll and Weick, 2008; StBA, 2004; Brög et al., 2000). 
Even so, there is little knowledge of elderly people's mobility opportunities, obstacles constraining their access to health care and their respective needs. Against this background, the aim of this study was to gain a basic understanding of older people's needs and problems in accessing rural health care, as well as other rural services and facilities of everyday importance.

\section{Study area}

\section{STUDY DESIGN AND CONDUCT}

The district of Holzminden, situated in southern Lower Saxony in Northern Germany (Fig. 2), is 15 to 20 years ahead regarding demographic change compared with other districts in Germany: demographic processes that are still to come in other regions have already begun. Compared with the rest of Lower Saxony, the district has a relatively high share of people aged over 65 years, which is going to increase in the near future (Fig. 3). The older they are, the higher the share of women: the gender ratio is 1,245 women to 1,000 men for the age cohort 65 years or older, and 1,692 women to 1,000 men for those 75 years or older (LSKN, 2010).

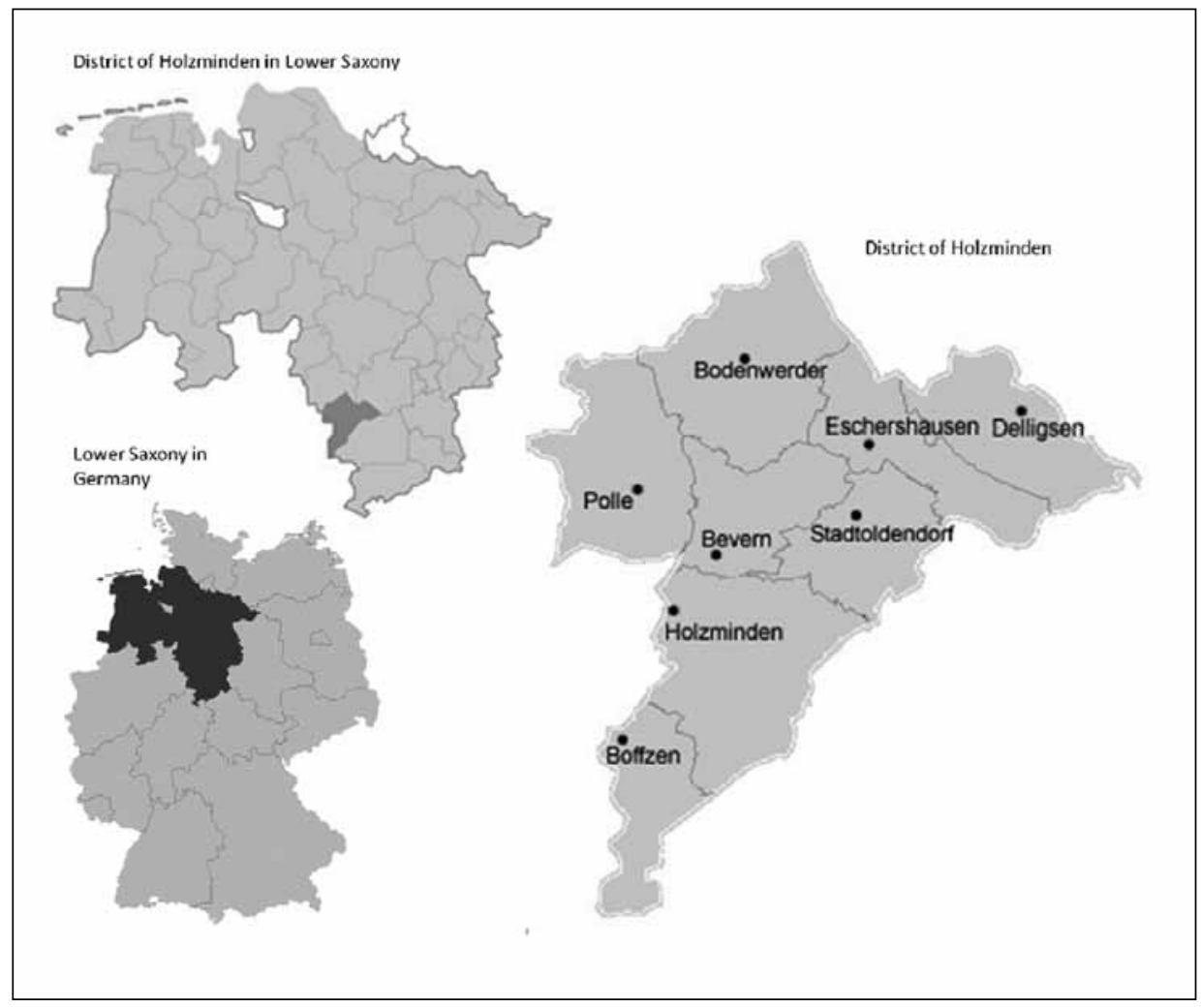

Fig. 2 Map of the district of Holzminden in Lower Saxony, Germany (Based on: Niedersachsen, 2011, modified)

Sl. 2. Karta okruga Holzminden u Donjoj Saskoj, Njemačka (prilagođeno prema: Niedersachsen, 2011). 


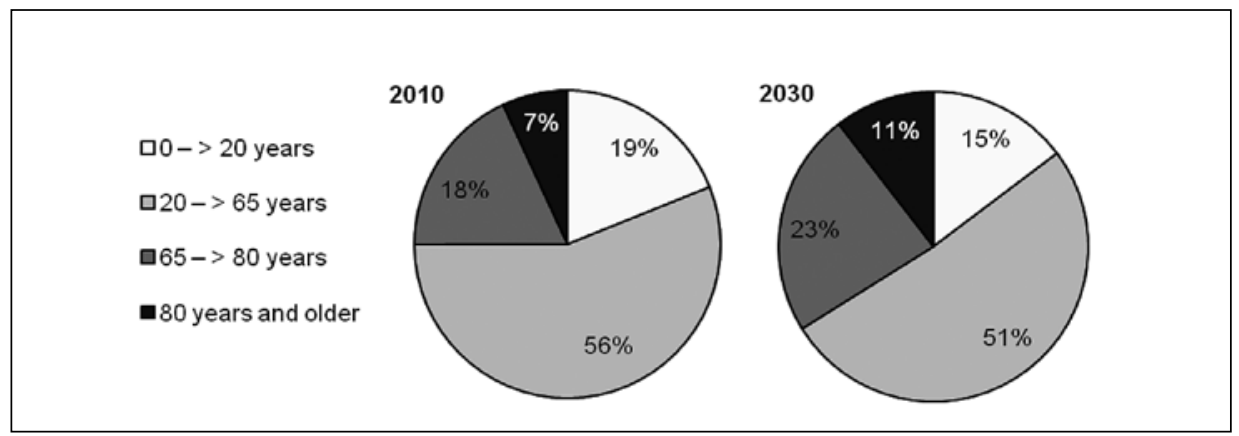

Fig. 3 Population: Age groups the district of Holzminden in 2010 and 2030

(Own design, according to data from: LSKN, 2011a; b)

S1. 3. Stanovništvo: Dobne skupine okruga Holzminden 2010. i 2030. godine (Autori, prema podacima iz: LSKN, 2011a; b).

Population density is quite low: 108 inhabitants per $\mathrm{km}^{2}$, which is about half of the German average (229). In the last 35 years, the population has declined by approximately $10 \%$. From now until 2021, the population is projected to decrease by about one sixth. By then, there will be only 67,000 inhabitants (19,000 older than 65 years), compared to 76,100 in 2007 and 89,000 at the beginning of the 1970s (Fig. 4).

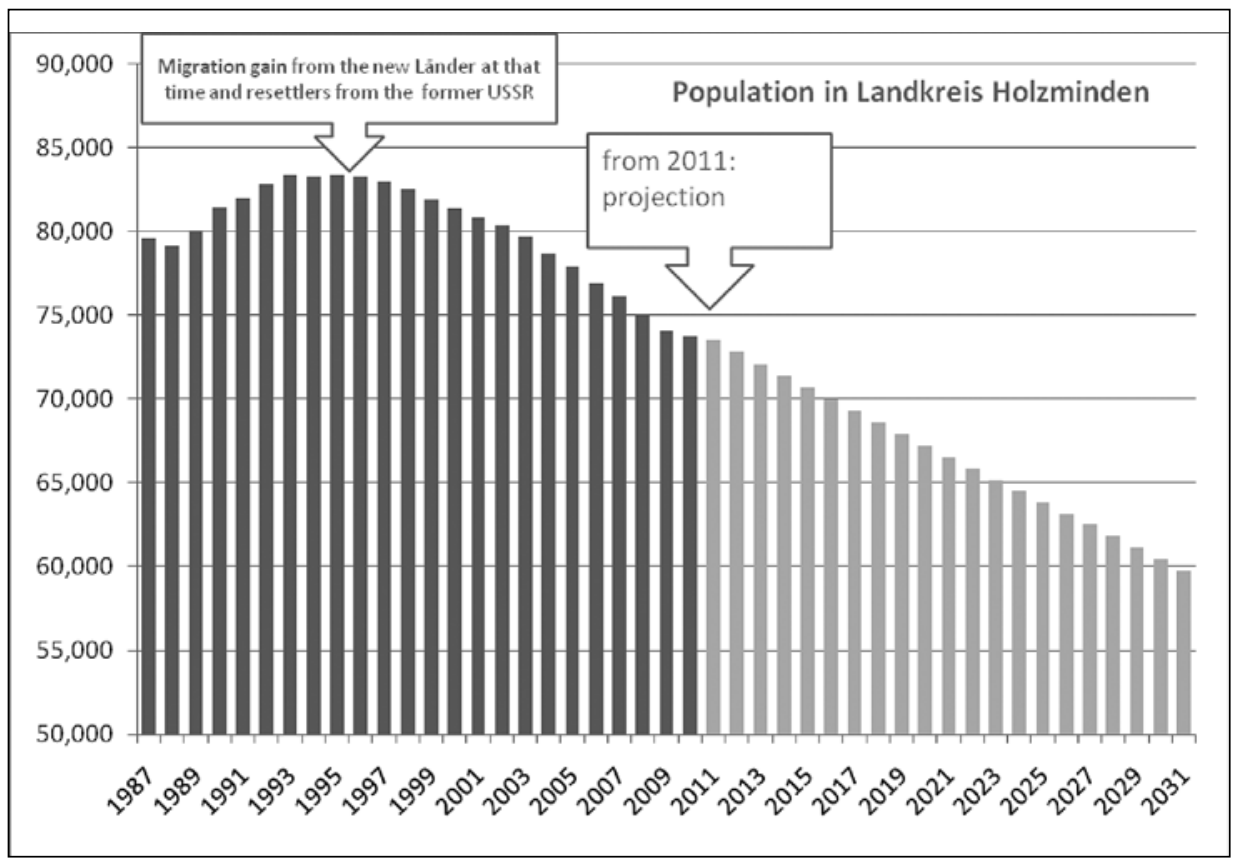

Fig. 4 Population development in Holzminden (from 2011: projected) (Own design, according to data from: LSKN, 2011a; b)

Sl. 4. Projekcija razvoja stanovništva u Holzmindenu, 2011. (Autori, prema podacima iz: LSKN, 2011a; b) 
This development is due to a natural deficit of births on the one hand, and net outward migration, mainly of the young and active generation, on the other. ${ }^{6}$ Within the district, there are intraregional differences; between 1968 and 2003 the Samtgemeinde (joint community) Bodenwerder has recorded the lowest shrinkage (-0.7\%), while the Samtgemeinde Eschershausen has lost $21 \%$ of its population in this 35 years period. These unfavourable demographic developments have an impact on all fields of communal action, ranging from even more financially limited room for manoeuvre to changing needs for local services and infrastructure. Among other, there is already a falling demand for childcare and schooling, and there will be a substantial increase in the need for senior-friendly housing, for residential and domiciliary care, for primary medical care and for public transport designed according to the requirements of elderly persons (Landkreis Holzminden, 2006; 2010; NLS, 2007).

\section{Methodology}

Seeing that health has an important psychological component (Böhm et al., 2009; Mielck, 2003), a qualitative research design was chosen in order to comprehend the individual's perceptions and experience of the subject. In-depth interviews were carried out by the first author with 25 men and women aged over 60 years of different life circumstances in various rural locations in the district of Holzminden at the beginning of 2010. Additionally, four focus group discussions were held, each group consisting of four female participants.

To ensure that topics relevant to the study were discussed and to achieve comparability of the results, an interview guide with open-ended key questions was used to macro-structure the conversations. The guideline covered not only health care issues, such as the provision of medical care and health-related quality of life, but also topics on daily activities and needs, close-by facilities and services and rural living in general.

Following the idea of theoretical sampling (Glaser and Strauss, 2005), our recruitment strategy combined purposeful and snowball sampling techniques. In the process of theoretical sampling, early results, that is, provisional theoretical ideas, served as criteria to decide what data should be gathered next. New participants were selected on the basis of their potential contribution to the development of a theory or to the validation of a theoretical construct. These samples are thus non-random and mostly small. Theoretical sampling can be considered a form of data triangulation and is generally associated with the development of grounded theory (see below) (Glaser and Strauss, 2005; Merkens, 2005; Ritchie and Lewis, 2003). First, we contacted groups where seniors would be met, such as men's choral societies, the Red Cross, seniors' sports groups, handicraft groups, a multi-generation house, and rural women's societies. Then we also asked participants to initiate contact to acquaintances with different life circumstances and/or who might have a different opinion on, perception of, or experience with the matters studied. The aim was to maximize variations within the sample, so that the results could be generalised to a certain extent (ibid.). In general, it was easier to find women ready to give an interview; although one third of the interviewees were male.

Participant interviews lasted between 30 minutes and one hour and were digitally recorded, transcribed and translated into English. Translating the quotations was challenging 
in that some German expressions do not have direct equivalents in English and many interviewees spoke in dialect, ungrammatically and used words in the wrong sense. To ensure the accuracy and consistency of the translations, an English lecturer checked the interview transcripts.

The interviews were constantly analysed using the constant comparative method. Constant comparison, hand in hand with theoretical sampling, is central in inductively developing a theory that is grounded in the collected data, forming and delineating categories, discerning patterns and discovering differences and similarities. New data are constantly compared with previous data, already partly analysed and reflected. Data were discussed to develop a coding framework, at first using 'in vivo codes', reflecting the participants' language. Issues and statements were then coded in response to recurring, contradictory and converging patterns accumulating different key concepts that, in doing so, emerged from the data. These themes were then grouped into formed and delineated categories. Subsequently, these were analysed to provide an explanation (see Corbin and Strauss, 1990; Glaser and Strauss, 2005). In the following section, selected categories of the broader, general concepts of health care and ageing in a rural area are presented with quotes to illustrate them.

\section{RESULTS}

Nearly all interviewees were married while a few women were widows. Except for one, all had children, mostly two or three. About a quarter of the interviewees lived in the same house with one of their children (albeit in a different flat) and said that they were happy about it: "I never thought that one would come back in the end. We had extended the house back then, a two-family house, and then no-one came." [Interviewee 16]

Except for one, all live in a household with at least one car. The large majority of 'young elderly people' (60 to 70 years old) are quite mobile and experience few obstacles in accessing health care facilities:

"That's what people are saying now, the 'new elderly', they will hopefully keep in good health a little longer." [5], "If I need something, I drive to the place where it is offered. " [15], "But many others sit here and spend their time looking around." [21]

Most driving license holders drive until an advanced age out of necessity and are happy that they are still able to do so: "It would be awful if I no longer had a car. It would be a punishment for me!'” [10]

Mostly, getting around by public transport is not possible or too complicated: "You need a car here. [...] First, public transport is ultra expensive, and then it is much pruned. [...] on Sundays you can't get anywhere." [5]

Those who cannot drive are thus dependent on their relatives (mainly on their spouse or children) or neighbours to be given a ride to all kinds of activities:

"Mychildren, of course, are ready. And I do have nice neighbours. And acquaintances, still." [16], "All that has to be done on a private basis." [8], "Well, if one cannot drive anymore, it is better to live in a city. " [7] 
Opinions on ageing in the rural space differ. For some, home is the most agreeable place to spend the evening of life:

"I want to tell you something, this whole thing, this process of ageing, of course it is most agreeable at home. I don't know if it is always agreeable. Of course, there's probably also a drawback." [17] Some find it quite hard in the countryside:

"When you're old [...] it is bad in the villages, very bad. [...] When we were younger, we didn't feel it like that. We were out and about a lot. [...] But now, in old age, one is, you know, it doesn't work like that anymore. " [21]

Even so, nearly none of the interviewees considers leaving the village:

"Here one has one's social contacts and acquaintances and now, I don't want any more, I am staying here." [2], "One knows everybody, that's it. On a first-name basis with everyone." [9], "Naaah. One has settled in here. Now somewhere else... You shouldn't shift an old tree." [11], "One is a bit rooted after all, if one has had one's own farm here for 40, 45 years." [15]. "If you have your property, like us, it is not that easy to move away." [7] (cp. below)

Many are aware that they might have to leave the village once they are not mobile anymore. Some consider moving to a home for the aged close by if necessary:

"They are building a new old people's home, and then, you just move there and then holidays at the children's place." [2]

Apparently, they are not in the minority:

"In this small place [...] Bodenwerder alone, there are five old people's homes! Five old people's homes! In this tiny place Bodenwerder. And crowded! They are all full!" [4]

Nearly all participants report that they have been to see a doctor recently and say that they do so quite regularly. Many primarily consult a close-by general practitioner but a large number also need to see medical specialists on a regular basis. Mentioned most frequently are ophthalmologists, dermatologists, urologists, diabetologists, and cardiologists.

Apart from long waiting times - "That really burns us up!" [11] -, most are rather satisfied with their family doctor - "That's a smart and capable one" [23] - and nearly all report long routes $(20-50 \mathrm{~km})$ to medical specialists and hospitals. It requires much time to keep an appointment with a specialist: "You spent half the day on the road. " [14]

Those who cannot drive, "they have to think thrice or they have to arrange with their relatives when they can drive them there" [22] and also neighbours help:

"In the village, we help each other." [25]

In one village in the study area, several women founded a group offering honorary transport to those "whom the children cannot drive." [4]

Some family doctors still make house calls but only if necessary:

"He also, well in a crucial situation, does make house calls. " [7] "They're not ready to do that much anymore." [15] "If it is absolutely necessary [...] But only when on duty, that is only during consulting hours." [21] 
This is considered to be of high importance:

"He also comes to you. [...] Well not for every crap, but if you had something serious, he would come. Thank goodness, we still have him. Hopefully, he'll still go on living for a while. Someone like him, we'll never get again, like that one. That's someone you can still call a doctor. He would even come on Christmas Day or Christmas Eve if it was necessary and wouldn't look at you all weird... He is great. That's Dr L. He's really a brilliant doctor." [24]

Age structure of general practitioners in the district of Holzminden shows a similar trend to that of the overall population:

"They are all already about 65, 66, many will quit." [10], "If they hadn't changed the law, he [the interviewee's family doctor, ed.] wouldn't even be allowed to practice anymore." [11]

In the up-coming years, many physicians in the district of Holzminden will retire but many have difficulties finding a successor (cp. below).

In some places there are already deficiencies in outpatient medical care:

"As to medical care, quite a lot is going pretty badly." [17]

Emergency care turns out to be especially problematic, and in some peripheral municipalities of the district it seems to fail completely:

"That has to do with, how they are positioned" [20], "Sometimes it's very quick, sometimes it can take a long time [...] That they have been waiting for the emergency doctor for half an hour. Having a heart attack one can't stand that well." [23], "That's how it is in the village. There are not so many doctors around after all. Or maybe only the. .. I don't know what, the foot doctor [...] who hasn't got a clue." [1]

Overall, the level of supply highly depends on the location. In some villages, health care and other services are still quite good:

"In this place here, there is everything - as yet." [20], "I think that actually, we are still quite well off. There are probably worse situations" [7]

By contrast, "Here in the village and also in Halle [neighbouring municipality, ed.] there is basically nothing." [4].

In most villages, formerly existing small shops closed some years ago. Since then, mobile bakeries and butcheries pass once or twice a week in some places. "A bakery, a butchery, actually there was everything, in the past. Everything is closed."

"We are left in the dust all over. Then the post office closed. Now, if we miss the postman, we have to travel $15 \mathrm{~km}$ to pick up a parcel. [...] an expensive parcel, that." [14]

Regarding organised leisure activities, a minority claim "Social life no longer exists in the countryside" [1], but most state that "what we do still have, that's nice, many clubs. "[14]

Most interviewees are members of at least one local club or society: "After allyou are involved in these clubs." [13] Most popular are the shooting clubs, auxiliary fire brigade, 
association of rural women, men's choral society, and the gymnastic club. The church plays a minor role regarding leisure activities. [16]

Many clubs have lost members: "My age group, they have all passed away already."

"'The choral society, that's 65+, no rather 70+. That's in danger of extinction." [6]

"Then they [the members of the local Red Cross, ed.] die off and there are no newcomers. " [7]

Young people leave the region because they do not find a job: "It's not getting better in the countryside. They all get the hell out of here." [7], "Few young families and few children. Because the infrastructure after all..., there are no jobs. And then it's obvious that people don't settle here." [21]

Job commuting is rarely possible: "We are located [...] in the middle of nowhere." [4] "You have to travel one hour before you see the motorway." [24]

As a consequence, children are rare: "I don 't think any child was born here last year!" [12], and kindergartens and schools have fewer and fewer children and some have already closed: "How many pupils we had! [...] Decreasing so rapidly. [...] we had nearly 400 pupils, now we have 120." [10]

Many houses are untenanted: "Can buy second-hand houses here, aplenty!" [3] Those who want to sell a house have difficulties in doing so: "I have been trying for four years now." [17]

Most regret this development - "It's a pity. But what can we do? We cannot influence it." [21] - and some express their dissatisfaction: "Let's be honest, politicians do everything to make it worse and worse here." [18]

As to elderly people's general attitude, nearly all appreciate the advantages of rural living:

"There is nice companionship, which is quite important when you're old. So, living in the country can be nice, too. You just have to make the best of it." [16]

"You have to have a positive attitude and must not think, uh, darn, I live out in the middle of nowhere, or something like that. You can't do that either." [4]

\section{DISCUSSION AND CONCLUSION}

About $90 \%$ of the German population sees a doctor at least once a year. Regularity and frequency of consultations increase substantially with age (Bergmann and Kamtsiuris, 1999; GBE, 2010). Nearly all men and women interviewed for this study reported that they needed to see a doctor quite regularly, both local family doctors and medical specialists; to consult the latter, they have to travel considerable distances. Given the poor public transport service in the district of Holzminden, just as in other rural areas in Germany, daily mobility highly depends on the availability of a car. With advancing age, maintaining mobility often becomes jeopardised due to the increasing risk of physical and sensory impairments (Mollenkopf and Flaschenträger, 2001). Many of the participants still drive 
and, overall, the elderly are getting more mobile, but still, the share of people driving a car decreases with age, and this more noticeably among women, because many elderly women have never held a driving licence (KBA, 2010; Noll and Weick, 2008; Brög et al., 2000). As this study shows, those who cannot drive are dependent on others to be given a ride to all kinds of activities. Mutual neighbourly help guarantees access to medical care and other important services for those whose children have moved away. If demographic developments, i.e., massive ageing and population decrease, occur as projected in the district of Holzminden, there will be a substantial rise in the number of older people, above all women, due to their higher life expectancy (StBA, 2010). At some point in some villages there might be too few people left who are able to give a ride to their immobile neighbours. Extending the bus service in ageing rural areas like the district of Holzminden would probably not improve elderly people's accessibility because - once not able to drive a car anymore - they are more likely to be in need of door-to-door transport, not only to hospital or medical appointments but also to shopping facilities or leisure activities. Alternative forms of demand-responsive transport already operate in some European countries that traditionally have a high share of rural population. Up to now, local projects offering such transport services to the elderly are mostly volunteer-run, filling the gaps that conventional services do not provide. Successful projects should be supported and can provide inspiration for new schemes in public transport and accessibility policy.

The change in the population's age structure, increasing age-related chronic diseases and (multi)morbidity will increase the number of patients and thus doctor-patient contacts that have to be considered in health care policy. Moreover, the above combined with the declining mobility of elderly people will very likely create a growing demand for house calls (Fendrich and Hoffmann, 2007; Van den Akker et al., 2001). These are problematic in combination with a diminishing doctor-patient ratio and long travel times in rural areas. Therefore, in both, ageing and rural areas, the doctor-population ratio has to be higher to assure sufficient provision with primary health care and emergency service. In some places of the study area, emergency service is already patchy and its reorganisation is obviously necessary to serve peripheral areas of the district. Whether the observed maladjustment to local and regional needs is a general problem in rural Germany cannot be said here.

Furthermore, the greater demand for certain medical specialists among the elderly assessed in this study, such as ophthalmologists, dermatologists, and urologists, has to be covered, and general practitioners may need higher geriatric qualification to medicate autonomously diseases typically affecting the elderly.

Even though the majority of patients are already aged, older people's specific needs have long been and still are neglected in rural and health care policy. In addition, gender aspects are often disregarded in transportation and health issues. Seeing gender differences, such as the percentage of driving license holders among the elderly (KBA, 2010), differing life expectancy (StBA, 2010) and disease patterns (e.g. Böhm et al., 2009) though, it is obviously important to apply gender sensitive approaches in research, policy and practice.

It should not be omitted that political awareness has increased substantially within the last year. Among other, it is considered to include a demographic factor in spatial requirement planning (GB-A, 2010). 
Even so, a large share of family doctors will retire in the coming years. According to the National Association of Statutory Health Insurance Physicians (NASHI; Kassenärztliche Bundesvereinigung, KBV), $18.1 \%$ of the practice-based doctors were aged 60 or older in 2008. The average age of statutory health insurance physicians was 51.7 years in 2008 (48.0 years in 1994). In some federal states up to $40 \%$ of the family doctors will retire in the next ten years. As the remaining doctors cannot fully compensate for these, their positions need to be refilled to provide sufficient primary care, but many country doctors experience problems with finding a successor.

Apparently, the advantages of rural living highlighted by the interviewees, such as quietness, community spirit, cheap housing and partly good schooling and leisure infrastructure do not outweigh low accessibility. The rural space is lacking attractiveness for the young and so is the working environment of a country doctor: high workloads due to house calls and on-duty medical service combined with declining profit rates (Schweikart, 2008).

So, Germany additionally faces the challenge to encourage (young) doctors to live and work in rural regions that will be or are already undersupplied. For this purpose, pilot projects have been launched in two Eastern federal states: medical students in Saxony-Anhalt are given financial support during their studies if they commit themselves to practice the first years after earning their degree in an undersupplied region in that particular state (KVSA, 2010). In Thuringia, young doctors qualifying as specialists for internal medicine or as general medical practitioners are supported financially if they work in undersupplied regions (Stiftung zur Förderung der ambulanten ärztlichen Versorgung im Freistaat Thüringen, 2010). These efforts to set incentives for medical students and young doctors to live and work in rural areas have not been well received as yet. Whether sufficient supply with country doctors can be attained in the end by such schemes, by higher remuneration in rural areas, by bonuses for house calls or by extra pay for treating elderly patients is an open question. In addition, improving the quality of life for young people in rural areas is the greatest and possibly only effective incentive.

\section{NOTES}

1 Well below the replacement level of 2.1 births per woman in Germany, i.e., the fertility rate needed to maintain population stability in the long term

2 Regional Planning Act, Raumordnungsgesetz, ROG 1998, § 2, paragraphs 2.1 and 2.4

3 In Germany, the establishment of doctors approved by public health insurance funds has been controlled by accreditation restrictions since 1993. Regulating how many doctors are admitted to practice in a planning region, this instrument was originally introduced in times with a growing number of physicians in order to prevent more practices in regions experiencing oversupply. Instead of oversupply, many regions face a shortage of doctors today. Requirement planning is made following calculations by the Federal Office for Building and Regional Planning, which takes account of settlement types. The population-family-doctor ratio is nearly equal in all types: in rural districts, 1,474 inhabitants per family doctor is defined as $100 \%$-supply, this ratio being slightly more favourable than in core cities of urban agglomerations (1,585 inhabitants per general practitioner). However, there are huge differences when it comes to medical specialists, e.g., in core cities there is supposed to be a $100 \%$-supply of urologists if 26,641 patients are allotted to one doctor, whereas in sparsely populated areas the ratio stands at 55,159 inhabitants per urologist (Schweikart, 2008). 
4 About $85 \%$ of the German population is mandatory or voluntary members of the public health insurance providers; the rest have a private health insurance. People can opt for private plans if their income exceeds a certain threshold or if they are self-employed.

5 The already enormous costs of the German health care system are rising, not only due to demographics but also to high long-term unemployment rates and immense costs for new technologies.

${ }^{6}$ Along with Osterode am Harz and Northeim, Holzminden is one of only three districts that are predicted to experience net outward migration in Lower Saxony.

\section{REFERENCES}

Bergmann, E., Kamtsiuris, P., 1999: Inanspruchnahme medizinischer Leistungen. Das Gesundheitswesen, 61 (Sonderheft), 138-44.

Böhm, K., Tesch-Römer, C., Ziese, T. (eds.), 2009: Gesundheit und Krankheit im Alter, Berlin: Robert KochInstitut, Statistisches Bundesamt, Deutsches Zentrum für Altersfragen.

Brög, W., Erl, E., Glorius, B., 2000: Elderly people's travel choices in Germany. In European Conference of Ministers of Transport (ed.) Transport and ageing of the population. Report of the 112th Round Table of Transport Economics, Paris 19.-20. Nov. 1998. Paris: OECD.

Bundesamt für Bauwesen und Raumordnung (BBR) (ed.), 2004: Bevölkerungsprognose 2020, Bonn.

BBR 2005: Raumordnungsbericht 2005, Bonn, Selbstverlag.

Bundesinstitut für Bau-, Stadt- und Raumforschung (BBSR) 2009: Medizinische Versorgung [Online]. Available: http://www.bbr.bund.de/cln_015/nn_77112/BBSR/DE/Raumbeobachtung/Themen/MedizinischeVersorgung/MedizinVersorgung_node.html?_nnn=true [Accessed 30.01.2010].

Bundesinstitut für Bevölkerungsforschung (BiB) 2009: Verlauf der demographischen Alterung [Online]. Wiesbaden. Available: http://www.bib-demografie.de/cln_099/nn_750730/DE/DatenundBefunde/Alterung/ verlauf_der_alterung.html [Accessed 12.12.2009].

Cassens, I., Luy, M., Scholz, R. (eds.), 2009: Die Bevölkerung in Ost- und Westdeutschland. Demografische, gesellschaftiche und wirtschaftliche Entwicklungen seit der Wende, Wiesbaden VS Verlag.

Corbin, J. M., Strauss, A. L., 1990: Grounded theory research: Procedures, canons, and evaluative criteria. Qualitative Sociology, 13 (1), 3-21.

Fendrich, K., Hoffmann, W., 2007: More than just aging societies: the demographic change has an impact on actual numbers of patients. Journal of Public Health, 15, 345-51.

Gemeinsamer Bundesausschuss (G-BA) 2010: Bedarfsplanungs-Richtlinie (Einführung eines Demografiefaktors) [Online]. Available: http://www.g-ba.de/informationen/beschluesse/zum-unterausschuss/7/\#1166/ [Accessed 20.08.2010].

Gesundheitsberichterstattung des Bundes (GBE) 2010: Ambulante ärztliche Versorgung in Prozent nach Alter, Geschlecht und sozialer Schicht, 2002/2003 [Online]. Available: http://www.gbe-bund.de/gbe10/ergebnisse. prc_fid_anzeige?p_fid $=9775 \& p \_$fund_typ $=T A B \& p \_s p r a c h k z=D \& p \_u i d=$ gast\&p_aid $=84656145 \& p \_p r o t=1$ [Accessed 02.02.2010].

Glaser, B. G., Strauss, A. L., 2005: Grounded theory: Strategien qualitativer Forschung, Bern, Huber.

Kassenärztliche Vereinigung Sachsen-Anhalt (KVSA) 2010: Stipendienprogramm für Medizinstudierende: Erste Stipendien vergeben [Online]. Available: http://www.kvsa.de/?cid=116027008144\&id=112027000004\& [Accessed 15.11.2010].

Kopetsch, T., 2005: Bedarfsplanung: Geregelt wird nur die Verteilung. Deutsches Ärzteblatt online, 06.05.2005, 1-6. 
Kraftfahrt-Bundesamt (KBA) 2010: Bestand an allgemeinen Fahrerlaubnissen im Zentralen Fahrerlaubnisregister (ZFER) am 1. Januar 2010 nach Geschlecht, Lebensalter und Fahrerlaubnisklassen [Online]. Flensburg: Kraftfahrt-Bundesamt. Available: http://www.kba.de/cln_015/nn_191454/DE/Statistik/Kraftfahrer/ Fahrerlaubnisse/Fahrerlaubnisbestand/2010_fe_b_geschlecht_alter_fahrerlaubnisk1.html [Accessed 30.10.2010].

Landesbetrieb für Statistik und Kommunikationstechnologie Niedersachsen (LSKN) 2010: Bevölkerung nach Alter, Geschlecht und Familienstand 2009, Hannover, LSKN.

LSKN 2011a: 100 Bevölkerungsfortschreibung (K1000014) [Online]. Available: http://www1.nls.niedersachsen. $\mathrm{de} /$ statistik/html/parametereingabe.asp?DT=K1000014\&CM=Bev\%F6lkerungsfortschreibung [Accessed 22.03.2011].

LSKN 2011b: Bevölkerungsvorausberechnung -Basisjahr 2009- (K1000014) [Online]. Available: http://www1. nls.niedersachsen.de/statistik/html/parametereingabe.asp?DT $=\mathrm{K} 1000014 \& \mathrm{CM}=\mathrm{Bev} \% \mathrm{~F} 6 \mathrm{kerungsfortschr}$ eibung [Accessed 22.03.2011].

LSKN 2011c: Bevölkerungsvorausberechnung: Vorausschätzung der Bevölkerung bis 2060 - Einzeljahre. [Online].Available: http://www.nls.niedersachsen.de/file/12KoordBevoelkerungsvorausberechnung_W1_NBB. xls [Accessed 22.03.2011].

Landkreis Holzminden 2006: Demographie-Bericht für den Landkreis Holzminden. Aktion Demographischer Wandel. Bertelsmann Stiftung [Online]. Available: http://www.landkreis-holzminden.de/pics/medien/1_1156761888/Demographie-Bericht_Stand_22-03-2006.pdf [Accessed 30.01.2010].

Landkreis Holzminden 2010: Demografischer Wandel im Blickpunkt. Der demografische Wandel als Chance für den ländlichen Raum - Gestaltung einer Modellregion Landkreis Holzminden [Online]. Available: http:// www.landkreis-holzminden.de/staticsite/staticsite.php?menuid=391\&topmenu=44 [Accessed 30.01.2010].

Merkens, H., 2005: Auswahlverfahren, Sampling, Fallkonstruktion. In Flick, U., Kardorff, E. \& Steinke, I. (eds.) Qualitative Forschung. Reinbek bei Hamburg: Rowohlt-Taschenbuch.

Mielck, A., 2003: Sozial bedingte Ungleichheit von Gesundheitschancen. Zeitschrift für Sozialreform, 49 (3), 370-5.

Mollenkopf, H., Flaschenträger, P., 2001: Erhaltung von Mobilität im Alter, Stuttgart, Kohlhammer.

Mollenkopf, H., Marcellini, F., Ruoppila, I., Széman, Z., Tacken, M. (eds.), 2005: Enhancing mobility in later life-Personal coping, environmental resources, and technical support. The out-of-home mobility of older adults in urban and rural regions of five European countries, Amsterdam: IOS Press.

Niedersachsen 2011: Landkreis Holzminden [Online]. Hannover. Available: http://www.niedersachsen.de/ image/19359 [Accessed 22.03.2011].

Niedersächsisches Landesamt für Statistik (NLS) 2007: Kleinräumige Bevölkerungsvorausberechnung für die Jahre 2012 und 2017 [Online]. Hannover: Niedersächsisches Landesamt für Statistik (NLS). Available: http://www.nls.niedersachsen.de/Applet/Prognose/P1000001.HTM [Accessed 12.09.2010].

Noll, H.-H., Weick, S., 2008: Lebenssituation von Älteren. In Statistisches Bundesamt (StBA), Noll, H.-H. \& Habich, R. (eds.) Auszug aus dem Datenreport 2008. Ein Sozialbericht für die Bundesrepublik Deutschland. Bonn: Bundeszentrale für politische Bildung.

Ritchie, J., Lewis, J. (eds.), 2003: Qualitative research practice: A guide for social science students and researchers, London [et al.]: Sage.

Robert Koch-Institut (RKI) 2006: Gesundheit in Deutschland, Berlin, Robert Koch-Institut.

Schweikart, J., 2008: Die große Herausforderung. LandInForm, 4, 12-3.

Statistisches Bundesamt (StBA) (ed.), 2004: Datenreport 2004. Zahlen und Fakten über die Bundesrepublik Deutschland, Bonn: Bundeszentrale für politische Bildung.

StBA2009: Bevölkerung Deutschlands bis 2060. 12. koordinierte Bevölkerungsvorausberechnung. Begleitmaterial zur Pressekonferenz am 18. November 2009 in Berlin [Online]. Wiesbaden. Available: http://www.destatis. $\mathrm{de} /$ jetspeed/portal/cms/Sites/destatis/Internet/DE/Presse/pk/2009/Bevoelkerung/pressebroschuere_bevoel kerungsentwicklung2009,property=file.pdf [Accessed 07.12.2009]. 
Elderly People's Perspective on Rural Medical Care - a Case Study from Northern Germany

StBA 2010: Life expectancy in Germany [Online]. Available: http://www.destatis.de/jetspeed/portal/cms/Sites/ destatis/Internet/EN/Content/Statistics/Bevoelkerung/GeburtenSterbefaelle/Tabellen/Content50/Lifeexpe ctancy,templateId=renderPrint.psml [Accessed 02.02.2010].

Stiftung zur Förderung der ambulanten ärztlichen Versorgung im Freistaat Thüringen 2010: Thüringen Stipendium [Online]. Available: http://www.stiftung-ambulante-versorgung.de/thringenstipendium/ [Accessed 15.11.2010].

Van den Akker, M., Buntinx, F., Roos, S., Knottnerus, J. A., 2001: Problems in determining occurence rates of multimorbidity. Journal of Clinical Epidemiology, 54, 675-9.

Received (Primljeno): 2010 - 12 - 22

Accepted (Prihvaćeno): $2011-03-23$

Eva Maria Noack

Georg-August-University of Göttingen enoack@uni-goettingen.de

\section{Holger Bergmann}

Georg-August-University of Göttingen hbergma1@uni-goettingen.de 
